\title{
Trump's presidency: the future of American tourism industry
}

Anh Viet Le

Anh Viet Le is a Lecturer at the Department of Higher Education, Holmes Institute Melbourne, Melbourne, Australia.
Received 30 November 2016 Revised 7 December 2016 Accepted 14 December 2016

( $)$ Anh Viet Le. Published in the Journal of Tourism Futures.

This article is published under the Creative Commons Attribution (CC BY 4.0) licence. Anyone may reproduce, distribute, translate and create derivative works of this article (for both commercial and non-commercial purposes), subject to full attribution to the original publication and authors. The full terms of this licence may be seen at http://creativecommons. org/licences/by/4.0/legalcode

\begin{abstract}
Purpose - The purpose of this paper is to provide the author's opinion about the future of American tourism under Trump's presidency.

Design/methodology/approach - This paper relies on secondary data.

Findings - The influences of Trump's presidency on American tourism will be on both sides. It will influence the destination image. It will also influence the relationships between America with several countries such as: China, Mexico, UK.

Originality/value - Contributes to the knowledge about the future of American tourism when the political system is changed.
\end{abstract}

Keywords American tourism, Trump's presidency

Paper type Viewpoint

Now, I know we have still not shattered that highest and hardest glass ceiling, but someday, someone will, and hopefully sooner than we might think right now (Hillary Clinton - Concession speech 2016).

It has been three weeks (at the time of writing) since the earth-shattering US election and yet the resonance of Donald Trump's ascension to the White House has not ceased. Americans were not the only ones astounded to see Donald trumping Hilary Clinton (pun intended) in an unprecedentedly close presidential race. Despite admirable efforts and favourable projections, it was Hilary's dream to become the first female president of the USA that was shattered instead of the "highest and hardest glass ceiling" (CNN, 2016b) that she mentioned in her speech.

Donald Trump, a billionaire, a businessman without any political experience whatsoever nonchalantly claimed the rights to proclaim himself the 45th American President. At the break of dawn, Tuesday 9 November, many believed that Hilary would never lose to Trump while her opposition did not deserve to win. However, as President Obama said "[...] regardless of whether your candidate won or lost, the sun would come up in the morning" and it is high noon that "making our economy work for everyone, not just those at the top, protecting our country and protecting our planet, and breaking down all the barriers that hold any American back from achieving their dreams" (should be utmost important) (White House, 2016).

Before the election, Hillary and Trump carry different perspectives in key issues, for example, in term of relationship China, Russia, social securities, trades, foreign policies and immigration. And now there is one big question hanging in the air: What will a Donald Trump presidency mean for USA and the world?

In my opinion, many industries in America will be influenced by the transfer of political power and certainly tourism will not be exempted.

Travel and tourism is the US largest service export, generating a \$98 billion trade surplus for the US economy in 2015. International visitors spent a record-breaking $\$ 246.2$ billion enjoying the USA, supporting 1.2 million jobs (ITA, 2016b).

A Donald Trump presidency will impact on tourism in both sides: negative and positive. 


\section{Negative side}

As indicated by Alvarez and Korzay (2008), political weather is massively portrayed by the medias and its outcomes affect the perception and reputation of a designated locale, ultimately of tourists. America is a hopeful, inclusive and big-hearted country (CNN, 2016b) but it has never been this divided. Anti-Trump protests and pro-Clinton strikes are everyday occurrence. In addition, under Trump's reign the USA would likely be forced to face a greater-than-ever sense of dread called terrorism because of its leader's eccentric personality and vulnerability:

"Terrorism is by definition a form of psychological warfare," says David Schanzer, director of the

Triangle Center on Terrorism and Homeland Security at Duke University (Adele Peter, 2016).

"The terrorists, by and large, are too weak to obtain their major objectives through their own actions", says David. "What they're trying to do is to get governments, societies, to overreact to provocations and actually damage their own societies themselves. That's what I would worry about from a Trump presidency, that he would essentially be an easy mark for psychological manipulation".

For once, Trump might respond by limiting his own people' freedom and rights through censorship and constraint, inadvertently damage his own country without the terrorists having to lift a finger. David believes that Donald's pompousness and eccentricity would only fuel the hatred against the enemy-swarmed USA, and increase the number of dangerous individuals over his tenure. Evidently ISIS advertisements have already used Donald Trump's images in their latest fiasco (Peter, 2016).

Due to said reasons, many Americans would lose faith in the future of their country under Donald Trump's leadership. The insecurity and instability would only fan the flame for terrorism and further jeopardise its tourism industry (Baker, 2014).

Second, America would squander its global influence. "If you look at people who support Trump internationally [...] it's really only people in countries that want the United States to fail", says lan Bremmer, president of the Eurasia Group, a firm that specialises in analysing large-scale global hazards.

"It's Hungary's Viktor Orbán, it's Kim Jong-un, it's Putin", he says. "If you talk to any of America's allies, even the Chinese, who are no fans of Hillary Clinton, they all desperately don't want to see Trump".

Because Trump makes crystal clear that he will be tunnel-visioning on America's greatness, the now-allies have a right to doubt their sense of trust in America. "Those countries would hedge their relations dramatically away from the U.S.", he says. The US role in spearheading the economic standard globally would be scrutinised and so would the value of US dollar:

"It would have a very negative impact on America's economic influence globally, over the long term, well beyond a single Trump administration," he says (Peter, 2016).

Actually we have evidences to state the following.

\section{With China}

Onward to the Pentagon, Trump repeatedly emphasised his diplomatic plans regarding relationship with other nations when he won the poll. He conceitedly looked down upon China's economic influence due to the volume of trade dealt by USA and believed the western nation holds advantage over the eastern powerhouse. The presidential businessman accuses China of undervaluing its currency and artificially inflate its trade competitiveness; in retaliation he plans to enforce a hefty 45 per cent on all Chinese imports if Beijing remains obstinate. Although such provocative act might not lead to a pacifistic end it is not certainly unthinkable for the inexperienced president to undertake things along the line.

In regards to tourism, the relationship between USA and China would take a heavy toll and ultimately the travel intention of Chinese to the USA. The number of international tourists departing from China is going to decrease and US tourism will take a loss. Since 2004 the growth of Chinese visitation in the USA could only be described as explosive, exhibiting double digit-growth in 11 of the last 12 years. Recently China has surpassed Brazil in visitors' shares as the fifth largest international market while topping the chart as the largest spending population. 
Specifically, Chinese tourists number around 3.3 per cent amongst global arrivals and yet expend more than US\$30.1 billion (ITA, 2016a). Within the last decade China has jumped from being eighth in terms of total travel spending to being first, averaging a staggering 25 per cent growth annually (ITA, 2016a). A loss of such stupendous investor would deal a massive blow to the US economy.

\section{With Mexico}

Mexico is no sloth either. There was around 18.43 million visits to America from its southern neighbour in 2015 (ITA, 2016a). And for the third consecutive year, the USA receive more Hispanic visits than ever before. The 18 million visits in 2015 was an increase of 8 per cent comparing to the last, signifying the sixth year in a row the USA has enjoyed a growth from her second largest market for international arrivals. In total, arrivals from Mexico accounted for roughly 24 per cent of all international arrivals to the USA (ITA, 2016a).

Mexican's expenditure also guarantees all possible attentions. Reaching $\$ 19.7$ billion in 2015, Mexico has been able to break its record for spending for three consecutive years. This number indicates a 4 per cent growth in comparison to the last and the sixth successive years of growth from the USA's backyard. More importantly, travel and tourism exports account for 62 per cent of all US services exports to Mexico (Euromonitor, 2016).

Given all that fact, Trump still insists on building his own "great, great wall" along the southern border of the USA to prevent "further illegal immigration". In addition, the inexperienced politician still has the audacity to make the very people he is trying to alienate pay for his ambition.

Just by attempting this policy, Trump and his supporters would engage in a lose-lose scenario. Both America and Mexico (if they, in any way conceivable, decide to contribute to wall) would suffer a massive financial blow to their budget. Furthermore, America would shrink her own income that arrives from Mexico. And the atrocious reputation of Trump's country would only chase away the potential Mexican tourists.

\section{With Cuba}

The ascension of Donald Trump could also mean unfavourable consequences to Cuba. For the past two years, Obama administration has been negotiating to normalise its relationship with the island after 50 years of Cold War hostility. He hopes that this would open up more opportunities for tourism and escalate into a tourism boom. Unfortunately, Trump has promised to invalidate this effort unless Cuba's president Raul Castro agrees to Trump's demand for more political power in his own nation.

Although Cuba is only just opening up to the USA, many Cuban have expressed their wishes to visit the much-awaited Land of Dream. Similarly, airlines and luxurious cruise ships have just begun delivering Americans to the dreamy tropical island and plenty of hotels are being constructed, waiting for their first tenants.

However, assuming Donald is a man of his word, the reversal of the historic agreement seems inevitable. If that is the case, are Americans and Cubans still able to travel?

The most apparent issue with Trump's policy is that it would only serve to delay investment into Cuba. Subsequently it would affect the construction of new hotels and other tourism-related infrastructure and ultimately hinder tourism (Stephanie, 2016).

However, some believe that on a more personal level, the soon-president may not necessarily break the pact between the two countries. After all, which businessman would not want to see his own hotels being opened in more cities and countries?

\section{With British}

According to The Independent, a leading British newspaper, they predict that as many as 1.8 million British travellers will not visit the USA next year as a direct result of Donald Trump's presidency. To ensure the significance of that number, it should be known that every year there are around 3.8 million British travelling to the USA. That means a drop of nearly 50 per cent compared to the year before. 
"Following confirmation of a win for Donald Trump in the presidential election today, we're now forecasting an unstable 2017 for US tourism, with over one million United Kingdom travellers set to reconsider the country as a holiday destination", said Joel Brandon-Bravo, UK Managing Director for Travelzoo, a travel booking website.

The prediction was based on a survey conducted by Travelzoo shortly before the unforeseen election. One in nine respondents would probably not visit the USA, while one in five would not even consider the USA a potential destination.

The displeasure was even stronger in the British capital. 30 per cent of Londoners announced that they would not fly across the ocean if Donald Trump were to be elected (Simon, 2016).

\section{Positive impact}

Besides many disadvantages that the US tourism industry might have to face with when Trump is President, some positive impacts are considered.

\section{New infrastructure}

In his victory speech, President Trump emphasised that "We are going to fix our inner cities and rebuild our highways, bridges, tunnels, airports, schools, hospitals. We're going to rebuild our infrastructure, which will become, by the way, second to none. And we will put millions of our people to work as we rebuild it” (CNN, 2016a).

On his way to presidency, Trump in many occasions had made promises to create more job opportunity in order to enhance economics. US $\$ 1$ trillion is the budget that he is willing to expend to deliver his oaths. On the other hand, the president has acknowledged that US airports are far behind in terms of world standard and would put forth an attempt to address this issue (ETB Travel News, 2016). Although commencement for new roads and airports has yet to be underway, the hope that new infrastructures will help improve the tourism industry is one to be longed for.

\section{Trump's experience in tourism industry}

Although new to the political scene, Trump is no stranger when it comes to tourism. Highly regarded as a billionaire before becoming US president, he has long been an active member of the tourism industry. It is plausible that he may be the most travel-friendly president in modern history whose possessions of hotels and accommodations spreads globally. His company has built and expanded hotels, resorts, golf courses and casinos in and out of America, from West to East. While not all have been commercially successful Trump has been able to set a high standard in services, comfort and appointments in luxury hotels and resorts (ETB Travel News, 2016). With experience in tourism, hospitality plus a business-minded mentality, Trump may make his case to allow USA to be a welcome and appealing destination (Stephanie, 2016).

\section{Conclusion}

In conclusion, at that moment, no one can give the correct answer for the future of American tourism under Trump's presidency. However, there are a number of factors that can have an influence on peoples travel decisions including political decisions, the threat of terrorism, civil/ world wars and natural disasters. That is the reason why we have evidences to believe that many political decisions made by Trump can influence tourism in both sides.

\section{References}

Alvarez, M.D. and Korzay, M. (2008), "Influence of politics and media in the perceptions of Turkey as a tourism destination", Tourism Review, Vol. 63 No. 2, pp. 38-46.

Baker, D.M.A. (2014), "The effects of terrorism on the travel and tourism industry", International Journal of Religious Tourism and Pilgrimage, Vol. 2 No. 1, pp. 58-67. 
CNN (2016a), "Here's the full text of Donald Trump's victory speech”, CNN, available at: http://edition.cnn. com/2016/11/09/politics/donald-trump-victory-speech/ (accessed 7 December 2016).

CNN (2016b), "Hillary Clinton's concession speech 2016”, CNN, available at: http://edition.cnn.com/2016/ 11/09/politics/hillary-clinton-concession-speech/ (accessed 24 November 2016).

ETB Travel News (2016), "President Trump and tourism”, available at: http://australia.etbtravelnews.com/30 7110/president-trump-tourism/ (accessed 6 December 2016).

EUROMONITOR Research (2016), "The 2016 elections and the US travel and tourism industry", EUROMONITOR, available at: http://blog.euromonitor.com/2016/11/the-2016-elections-and-the-us-traveland-tourism-industry.html (accessed 14 November 2016).

ITA (2016a), available at: http://tinet.ita.doc.gov/about/tourism_policy.asp (accessed 14 November 2016).

ITA (2016b), "Top 10 international markets: visitation and spending, international trade administration”, ITA, available at: http://tinet.ita.doc.gov/pdf/2015 Top 10 Markets.pdf (accessed 24 November 2016).

Peter, A. (2016), "How a Trump presidency would ruin the long term future", Fascoexist, available at: www.fastcoexist.com/3064731/how-a-trump-presidency-would-ruin-the-long-term-future (accessed 14 November 2016).

Simon, C. (2016), "One million fewer British visitors to the US' predicted as prospective tourists react to Trump's victory - American travel industry alarmed at the prospect of a 'trumpaggedon' boycott", The Independent, available at: www.independent.co.Uk/travel/americas/us-election-president-trumpvictory-america-tourism-a7407316.html (accessed 14 November 2016).

Stephanie, R. (2016), "What impact will Trump have on tourism?", available at: www.nytimes.com/2016/11/ 10/travel/trump-travel-tourism.html?_r=0 (accessed 14 November 2016).

White House (2016), "President Obama speaks results election 2016", available at: www.whitehouse.gov/ blog/2016/11/09/president-obama-speaks-results-election (accessed 24 November 2016).

\section{Further reading}

Accidental Travel Writer (2016), available at: www.accidentaltravelwriter.net/2016/11/what-impact-willdonald-trumps-presidency-have-on-inbound-tourism.html (accessed 14 November 2016).

The Australian (2016), "US election 2016: where Hillary Clinton and Donald Trump stand on key issues", available at: www.theaustralian.com.au/in-depth/us-politics/us-election-2016-where-hillary-clinton-and-donald-trumpstand-on-key-issues/news-story/c9a4b1f832705f49337ee80333834116 (accessed 9 November 2016).

Travelweek (2016), "Trump White House impact global travel tourism”, available at: www.travelweek.ca/ news/trump-white-house-impact-global-travel-tourism/ (accessed 14 November 2016).

\section{Corresponding author}

Anh Viet Le can be contacted at: vithvtc@yahoo.com

For instructions on how to order reprints of this article, please visit our website:

www.emeraldgrouppublishing.com/licensing/reprints.htm

Or contact us for further details: permissions@emeraldinsight.com 